\title{
PENDUGAAN EROSI DI LAHAN KERING DENGAN METODE USLE DI SUB SUB DAS DENGKENG KECAMATAN BULU DAN WERU KABUPATEN SUKOHARJO PROVINSI JAWA TENGAH
}

\section{SOIL EROSION PREDICTION ON DRYLAND USING USLE METHOD AT DENGKENG SUB-SUB WATERSHED IN BULU AND WERU SUB DISTRICT SUKOHARJO DISTRICT CENTRAL JAVA PROVINCE}

\author{
Novita Andarwati ${ }^{1)}$, A. Z. Purwono Budi Santoso ${ }^{2) *}$, M. Nurcholis ${ }^{2)}$ \\ ${ }^{1)}$ Prodi Agroteknologi, Universitas Pembangunan Nasional Veteran Yogyakarta \\ 2) Prodi Ilmu Tanah, Universitas Pembangunan Nasional Veteran Yogyakarta \\ ${ }^{*}$ Corresponding author E - mail: pbudisant@yahoo.com
}

\begin{abstract}
Soil erosion refers to the process of soil being destroyed, eroded, transported or deposited by external forces, especially rainfall. Soil erosion impacts soil fertility reduction and topsoil loss as fertile layer for plant growth media and root development. Plant cultivation on hilly area has several problems such as relatively steep slopes, higher soil erodibility and rainfall. In the watershed, erosion can impact silting river up because of accumulated soil sediment. The research was aimed to determine value of erosion and mapping distribution of erosion. The research was conducted at 288 hectare Dengkeng sub-sub watershed in Bulu and Weru Sub-district Sukoharjo District. Sample points were obtained by purposive sampling method from an overlay process of slope and landuse map. This research had five parameters, those were rainfall erovisity index, organic matter percentage, soil texture, structure, permeability, length and slope index, crop management index and conservation index. Prediction of erosion value based on Universal Soil Loss Equation method then classified by Department of Forestry. The result showed rainfed paddy field landuse on steep slope as the highest prediction of erosion value which was 600,64 ton/ha/year or 40,04 mm/year, meanwhile the lowest prediction of erosion value was settlement landuse on flat slope of $4,54 \mathrm{ton} / \mathrm{ha} /$ year or $0,30 \mathrm{~mm} / \mathrm{year}$. Heavy erosion class was the widest deployment of 175,27 ha on Kedung Lanang Orchard, Karangmojo Village.
\end{abstract}

Keywords: Dengkeng Sub-sub Watershed, Erosion Prediction, USLE Method

\begin{abstract}
ABSTRAK
Erosi tanah merupakan proses penghancuran, pengikisan, pengangkutan, atau penyimpanan tanah dari materi eksternal, yaitu hujan. Erosi mengakibatkan penurunan kesuburan tanah dan hilangnya top soil sebagai lapisan tanah yang subur untuk media tumbuh tanaman dan berkembangnya akar. Budidaya tanaman di daerah yang berbukit-bukit memiliki beberapa masalah seperti lereng yang relatif curam, kepekaan tanah terhadap erosi dan curah hujan yang tinggi. Pada daerah aliran sungai, erosi dapat mengakibatkan pendangkalan badan sungai karena sedimen tanah yang menumpuk. Tujuan penelitian ini untuk menetapkan besarnya potensi erosi yang ada dan peta penyebaran erosi. Penelitian dilaksanakan di sub-sub DAS Dengkeng Kecamatan Bulu dan Weru, Kabupaten Sukoharjo seluas 288 ha. Titik sampel ditentukan dengan metode purposive sampling dari hasil tumpangsusun peta kemiringan lereng dan tataguna lahan. Parameter penelitian ini
\end{abstract}


adalah nilai erosivitas hujan, bahan organik, tekstur, struktur, permeabilitas tanah, indeks panjang dan kemiringan lereng, indeks nilai $\mathrm{C}$ dan nilai P. Pendugaan nilai erosi dihitung menggunakan Metode USLE (Universal Soil Loss Equation) yang dikelaskan menurut Kementerian Kehutanan. Hasil penelitian ini menunjukkan bahwa penggunaan lahan sawah tadah hujan pada kemiringan curam memiliki nilai pendugaan erosi tertinggi yaitu 600,64 ton/ha/tahun atau 40,04 mm/tahun, sedangkan pada lahan pemukiman dengan kemiringan lereng datar memiliki nilai pendugaan erosi terkecil yaitu 4,54 ton/ha/tahun atau $0,30 \mathrm{~mm} /$ tahun. Kelas erosi berat memiliki penyebaran paling luas yaitu 175,27 ha dengan penyebaran terluas di Dusun Kedung Lanang, Desa Karangmojo.

Kata Kunci: Sub-sub DAS Dengkeng, Pendugaan Erosi, Metode USLE

\section{PENDAHULUAN}

Sungai pada suatu wilayah menjadi penampung air yang tidak terserap ke dalam tanah dan mengalir ke tempat yang lebih rendah. Erosi di daerah hulu dapat mengakibatkan pendangkalan badan sungai karena sedimen yang menumpuk. Hal ini terjadi karena lapisan permukaan tanah bagian hulu menipis dan mampu menurunkan kemampuan tanah dalam menahan air. Daerah penelitian di Sub-sub DAS Dengkeng berada di Desa Sanggang, Kecamatan Bulu dengan sebagian kecil berada di Desa Alasombo dan Desa Karangmojo, Kecamatan Weru, Kabupaten Sukoharjo. Daerah penelitian ini memiliki luas berkisar 288 ha dengan kemiringan lereng yang ada berkisar 3 - $42 \%$ dan mempunyai ketinggian $140-380 \mathrm{~m}$ di atas permukaan air laut (mdpl). Daerah dengan topografi berbukit- bukit ini diperkirakan memiliki nilai erosi yang rendah sampai tinggi dikarenakan belum meratanya pengelolaan konservasi tanah yang baik pada kemiringan lereng yang curam. Jenis tanah yang terdapat di desa ini yaitu Litosol yang termasuk dalam jenis tanah Entisol. Tanah ini merupakan tanah baru berkembang dan cukup peka terhadap erosi. Daerah penelitian ini terletak pada perbukitan dengan dominasi perkebunan tanaman tahunan yang memiliki kemiringan lereng yang berbedabeda dengan pengelolaan konservasi tanah yang beragam. Keadaan ini dapat menimbulkan perbedaan pendugaan nilai erosi tanah yang dapat menurunkan kesuburan tanah.

\section{BAHAN DAN METODE}

Penelitian dilakukan di Sub-sub Daerah Aliran Sungai Dengkeng yang berada di sebagian besar Desa Sanggang, Kecamatan Bulu dengan sebagian kecil Desa Alasombo dan Karangmojo, Kecamatan Weru, Kabupaten Sukoharjo. Bahan yang digunakan Peta Topografi, Peta Penggunaan Lahan, Peta Administrasi, data curah hujan, sampel tanah dari setiap titik sampel dan bahan kimia untuk keperluan analisis. Penelitian dilakukan dengan metode survei untuk memperoleh data panjang dan kemiringan lereng, nilai $\mathrm{C}$, nilai $\mathrm{P}$ dan struktur tanah. Metode penentuan titik sampel adalah metode purposive sampling yang berdasarkan pada penggunaan lahan kering, kemiringan lereng dan pertimbangan luas daerah pada setiap satuan lahan dengan jumlah titik sampel sebanyak 22 titik. Titik sampel diperoleh dari Peta Sistem Lahan dengan skala 1 : 12.500 yang merupakan hasil overlay Peta Penggunaan Lahan dan Peta Kemiringan Lereng menggunakan aplikasi ArcGIS 10.2. 
Prediksi besarnya erosi dihitung dengan Metode USLE (Universal Soil Loss Equation) dengan rumus sebagai berikut:

$$
A=\text { R. K. LS. C. P }
$$

Keterangan:

A = Berat tanah yang hilang per hektar (ton/ha/th)

$\mathrm{R}=$ Faktor erosivitas hujan $\mathrm{K}=$ Faktor erodibilitas tanah

LS = Faktor gabungan panjang dan ketajaman lereng

$\mathrm{C} \quad=$ Faktor penutup oleh tanaman dan pengelolaan tanaman

$\mathrm{P} \quad=$ Faktor praktis pengontrol erosi atau faktor tindakan khusus konservasi tanah

Faktor Erosivitas Hujan (R)

$$
\mathrm{Rm}=2,21(\text { Rain })_{\mathrm{m}} 1,36
$$

Keterangan:

(Rain) $\quad=$ Rata-rata jumlah hujan bulanan $(\mathrm{cm} / \mathrm{bulan})$

\section{Faktor Erodibilitas Tanah (K)}

$$
100 \mathrm{~K}=2,1 M^{1,14}\left(10^{-4}\right)(12-a)+3,25(b-2)+2,5(c-3)
$$

Keterangan:

$\mathrm{K}=$ Erodibilitas

$\mathrm{M}=$ Ukuran partikel (\% debu $+\%$ pasir sangat halus) (100 - \%lempung)

$\mathrm{a}=$ Kandungan bahan organik $\mathrm{b}=$ Kelas struktur tanah

$\mathrm{c}=$ Kelas permeabilitas

\section{Faktor Panjang dan Kemiringan Lereng (LS)}

$$
L S=\sqrt{X\left(0,0138+0.00965 s+0.00138 S^{2}\right.}
$$

Keterangan:

$\mathrm{X} \quad=$ panjang lereng $(\mathrm{m})$

$\mathrm{S} \quad=$ kecuraman lereng $(\%)$

\section{Faktor Pengelolaan Tanaman (C)}

Berdasarkan Tabel Nilai Faktor C dengan Tanaman Tunggal dan Nilai Faktor C dengan Berbagai Pengelolaan Tanaman menurut Abdulrachman dan Hammer (1981)

Faktor Tindakan Konservasi Tanah (P)

Berdasarkan Nilai Faktor Konservasi Lahan (P) menurut Asdak (2002) 


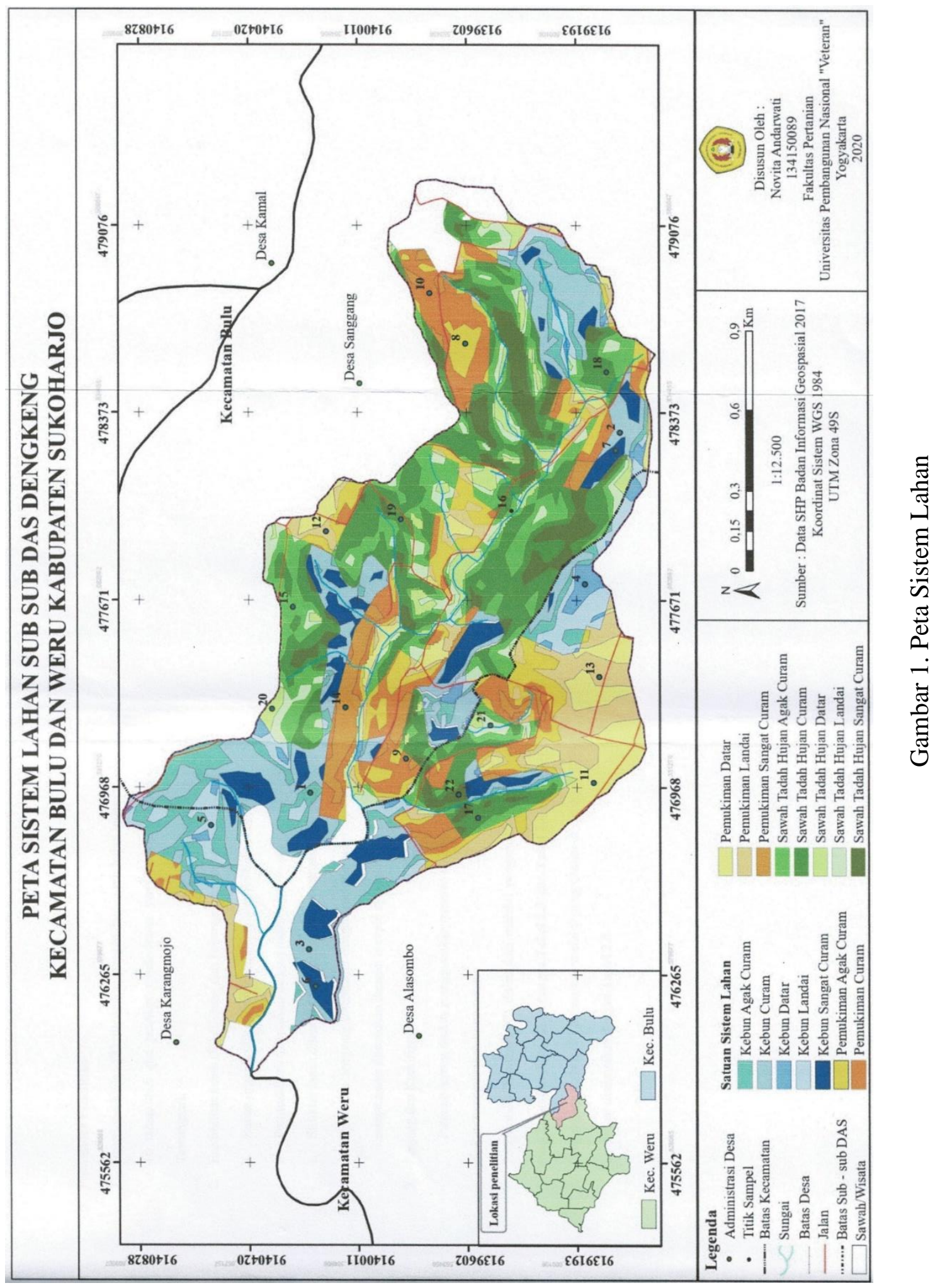




\section{HASIL DAN PEMBAHASAN}

\section{Faktor Erosivitas Hujan (R)}

Data diperoleh dari curah hujan bulanan dari Kecamatan Tawangsari periode Januari 2010 - Desember 2019 yang diperoleh dari BMKG (Badan Meteorologi Klimatologi dan Geofisika) Jawa Tengah dan Balai Penyuluhan Pertanian (BPP) Grajegan, Tawangsari, Sukoharjo. Nilai erosivitas hujan disajikan pada Tabel 1.

Tabel 1. Erosivitas Hujan Selama 10 Tahun

\begin{tabular}{clccc}
\hline No & Bulan & $\begin{array}{c}\text { Rerata Curah } \\
\text { Hujan }(\mathbf{c m})\end{array}$ & R & R Tahunan \\
\hline 1 & Januari & 33,58 & 262,94 & \\
2 & Februari & 34,11 & 268,60 & \\
3 & Maret & 26,75 & 193,00 & \\
4 & April & 22,63 & 153,76 & \\
5 & Mei & 12,02 & 65,02 & \\
6 & Juni & 8,40 & 39,94 & \\
7 & Juli & 2,39 & 7,23 & 1404,92 \\
8 & Agustus & 2,46 & 7,52 & \\
9 & September & 7,03 & 21,13 & \\
10 & Oktober & 9,93 & 50,15 & \\
11 & November & 21,21 & 140,76 & \\
12 & Desember & 26,94 & 194,86 & \\
\hline
\end{tabular}

Nilai R tahunan yaitu 1.404,92 (MJ.mm/ha.jam/tahun) (As-syakur, 2008). Nilai $\mathrm{R}$ tertinggi terdapat pada bulan Februari yang juga memiliki nilai curah hujan paling banyak. Menurut Vrieling et al. dalam Shanshan et al. (2018), erosivitas hujan merepresentasikan kekuatan erosi oleh air hujan dan mengakibatkan runoff, meliputi pelepasan partikel-partikel pada permukaan tanah oleh energi kinetik air hujan dan mengangkut partikel- partikel tanah melalui aliran permukaan. Apabila sering terjadi hujan deras pada bulan Februari, maka akan sering terjadi pengangkutan partikelpartikel tanah terutama pada daerah tanpa vegetasi dengan kemiringan lereng tinggi.

\section{Faktor Erodibilitas Tanah (K)}

Erodibilitas tanah merupakan indeks kepekaan tanah terhadap erosi yang menunjukkan mudah tidaknya tanah mengalami erosi. Nilai erodibilitas tanah disajikan pada Tabel 2. Berdasarkan perhitungan pada Tabel 2 dapat diketahui bahwa nilai $K$ pada daerah penelitian berkisar dari 0,03 sampai dengan 0,55 ton.ha.jam/ha.MJ.mm (Assyakur, 2008). Hal ini dipengaruhi oleh kandungan bahan organik, kecepatan permeabilitas, kemantapan agregat pada struktur dan banyaknya perbandingan fraksi-fraksi tanah. Menurut Veihe (2001), kemantapan agregat yang rendah mengindikasi tanah-tanah pertanian memiliki erodibilitas yang tinggi. Menurut Wischmeier dan Mannering dalam Dariah et al., (2004), secara umum tanah dengan kandungan debu tinggi, lempung rendah dan bahan organik rendah adalah yang paling mudah tererosi. 
Tabel 2. Erodibilitas Tanah (K)

\begin{tabular}{|c|c|c|c|c|c|c|}
\hline No & Titik Sampel & M & $\begin{array}{c}\text { KBO } \\
(\%)\end{array}$ & $\begin{array}{c}\text { Kode } \\
\text { Struktur }\end{array}$ & $\begin{array}{c}\text { Kode } \\
\text { Permeabilitas } \\
(\mathrm{cm} / \mathrm{jam}) \\
\end{array}$ & $\mathbf{K}$ \\
\hline 1 & Kebun $-\mathrm{AC}$ & 5497,35 & 2,69 & 4 & 2 & 0,40 \\
\hline 2 & Kebun $-\mathrm{C} 1$ & 2747,27 & 3,83 & 4 & 4 & 0,23 \\
\hline 3 & Kebun $-\mathrm{C} 2$ & 4017,81 & 2,33 & 2 & 4 & 0,29 \\
\hline 4 & Kebun - D & 735,35 & 2,71 & 1 & 4 & 0,03 \\
\hline 5 & Kebun - L & 6163,84 & 1,83 & 1 & 3 & 0,41 \\
\hline 6 & Kebun - SC 1 & 3492,89 & 3,00 & 4 & 5 & 0,32 \\
\hline 7 & Kebun - SC 2 & 3513,33 & 3,77 & 2 & 5 & 0,24 \\
\hline 8 & Pemukiman - AC & 4748,94 & 2,41 & 2 & 4 & 0,34 \\
\hline 9 & Pemukiman - C 1 & 2030,99 & 2,42 & 3 & 5 & 0,20 \\
\hline 10 & Pemukiman - C 2 & 2983,01 & 3,49 & 4 & 5 & 0,28 \\
\hline 11 & Pemukiman - D & 1248,73 & 2,11 & 4 & 4 & 0,16 \\
\hline 12 & Pemukiman - L1 & 2832,34 & 3,30 & 2 & 4 & 0,18 \\
\hline 13 & Pemukiman - L2 & 2173,52 & 3,70 & 4 & 5 & 0,23 \\
\hline 14 & Pemukiman - SC & 2000,54 & 3,07 & 2 & 4 & 0,13 \\
\hline 15 & Sawah Tadah Hujan - AC 1 & 2315,29 & 3,28 & 2 & 3 & 0,13 \\
\hline 16 & Sawah Tadah Hujan - AC 2 & 5287,33 & 3,34 & 1 & 4 & 0,31 \\
\hline 17 & Sawah Tadah Hujan - C 1 & 5953,42 & 0,30 & 3 & 4 & 0,55 \\
\hline 18 & Sawah Tadah Hujan - C 2 & 5994,11 & 2,06 & 2 & 4 & 0,39 \\
\hline 19 & Sawah Tadah Hujan - C 3 & 5576,44 & 3,65 & 2 & 4 & 0,35 \\
\hline 20 & Sawah Tadah Hujan - D & 3432,79 & 3,94 & 4 & 4 & 0,27 \\
\hline 21 & Sawah Tadah Hujan - L & 2318,03 & 2,87 & 4 & 3 & 0,20 \\
\hline 22 & Sawah Tadah Hujan - SC & 2582,01 & 3,82 & 4 & 3 & 0,20 \\
\hline
\end{tabular}

Keterangan: $\mathrm{KBO}=$ Kadar Bahan Organik; $\mathrm{AC}=$ Agak Curam; $\mathrm{C}=$ Curam; $\mathrm{D}=$ Datar; $\mathrm{L}=$ Landai; $\mathrm{SC}=$ Sangat Curam

\section{Topografi (LS)}

Peran topografi yang menentukan besar kecilnya erosi adalah panjang dan kemiringan lereng. Data yang diperoleh disajikan pada Tabel 3. Berdasarkan data yang ada, titik sampel Sawah Tadah Hujan Sangat Curam memiliki nilai LS paling besar dikarenakan besarnya kemiringan lereng yang diikuti besarnya panjang lereng. Menurut Suryanto dan Wawan (2017), tingkat kemiringan lahan meningkatkan aliran permukaan. Hal ini disebabkan karena kemiringan lahan memiliki perbedaan gaya berat (gravity). Pada lahan yang lebih miring gaya berat bekerja lebih tinggi dibandingkan dengan kemiringan ang lebih rendah. Perbedaan ini menyebabkan kemampuan tanah untuk menahan air lebih rendah karena tanah mempunyai sedikit pori- pori halus yang dapat diisi air.

\section{Vegetasi $(C)$}

Daerah pengambilan sampel memiliki tiga jenis penggunaan lahan yaitu kebun, pemukiman dan sawah tadah hujan. Penggunaan lahan sawah tadah hujan ditanami komoditas yang beragam saat musim kemarau, seperti serai wangi, ubi kayu dan kebun campuran. Di beberapa titik sampel, pengelolaan tanaman berupa kebun campuran tidak dapat berubah menjadi sawah saat musim hujan, karena tanaman yang ada berupa tanaman tahunan dengan semak dan rerumputan yang tidak terawat dengan baik. Data pengelolaan tanaman disajikan dalam Tabel 4. 
Tabel 3. Panjang dan Kemiringan Lereng (LS)

\begin{tabular}{clccc}
\hline No & \multicolumn{1}{c}{ Titik Sampel } & L $(\mathbf{m})$ & S (\%) & LS \\
\hline 1 & Kebun - AC & 134 & 24 & 11,81 \\
2 & Kebun - C 1 & 33 & 28 & 6,71 \\
3 & Kebun - C 2 & 108 & 35 & 14,85 \\
4 & Kebun - D & 108 & 3 & 1,94 \\
5 & Kebun - L & 37 & 15 & 4,17 \\
6 & Kebun - SC 1 & 105 & 40 & 16,55 \\
7 & Kebun - SC 2 & 110 & 44 & 18,50 \\
8 & Pemukiman - AC & 28 & 25 & 5,59 \\
9 & Pemukiman - C 1 & 23,7 & 26 & 5,36 \\
10 & Pemukiman - C 2 & 26 & 30 & 6,34 \\
11 & Pemukiman - D & 42 & 5 & 2,01 \\
12 & Pemukiman - L1 & 38,05 & 14 & 3,99 \\
13 & Pemukiman - L2 & 52 & 9 & 3,32 \\
14 & Pemukiman - SC & 72 & 42 & 14,33 \\
15 & Sawah Tadah Hujan - AC 1 & 125 & 25 & 11,82 \\
16 & Sawah Tadah Hujan - AC 2 & 35 & 15 & 3,87 \\
17 & Sawah Tadah Hujan - C 1 & 128 & 30 & 14,06 \\
18 & Sawah Tadah Hujan - C 2 & 40 & 26 & 6,92 \\
19 & Sawah Tadah Hujan - C 3 & 81 & 28 & 10,52 \\
20 & Sawah Tadah Hujan - D & 82 & 8 & 3,83 \\
21 & Sawah Tadah Hujan - L & 56 & 15 & 5,13 \\
22 & Sawah Tadah Hujan - SC & 98 & 50 & 19,67 \\
\hline Keteran
\end{tabular}

Keterangan: $\mathrm{AC}=$ Agak Curam; $\mathrm{C}=$ Curam; $\mathrm{D}=$ Datar; $\mathrm{L}=$ Landai; $\mathrm{SC}=$ Sangat Curam; L $(\mathrm{m})=$ Panjang Lereng; $\mathrm{S}(\%)=$ kemiringan lereng

Vegetasi kebun campuran memiliki nilai paling kecil dan ubi kayu memiliki nilai paling besar. Kebun campuran memiliki nilai yang kecil, karena kebun campuran terdiri dari tanaman tahunan dan semak- semak yang menutupi tanah secara rapat. Menurut Septianugraha dan Suriadikusumah (2014), penggunaan hutan memiliki vegetasi yang rapat dan banyaknya serasah dari sisa-sisa tanaman yang terdekomposisi sehingga menjadi asupan C-organik ke dalam tanah.

Dalam hal ini, kebun campuran dapat dikatakan penggunaan hutan karena terdapat banyak tanaman tahunan dengan semak yang tumbuh liar di daerah tersebut. Sedangkan pada tanaman ubi kayu, kerapatan vegetasi berbeda dengan kebun campuran, tidak terdapat semak-semak dan rerumputan, sehingga air hujan langsung mengenai tanah dan dengan mudah mendispersi partikel-partikel tanah. Hal ini menjadikan tanaman ubi kayu memiliki nilai pengelolaan tanaman yang lebih tinggi.

\section{Tindakan Konservasi Tanah (P)}

Data pengelolaan tanah dan tindakan konservasi tanah disajikan dalam Tabel 4. Teras bangku jelek dapat menekan erosi yang terjadi namun tidak begitu baik. Menurut Idjudin (2011), teras bangku tidak dianjurkan pada tanah yang bersolum dangkal dan kemiringannya sangat terjal ( $>40 \%)$. Pada tanah yang dangkal dianjurkan membuat teras gulud, budidaya lorong, atau pagar hidup. Semua jenis teras harus disertai dengan penanaman tanaman penguat teras, seperti rumput dan legum. Tanaman perkebunan penutup sedang memiliki nilai lebih besar dari teras bangku. 
Hal ini dikarenakan besar kemungkinan pemecahan agregat tanah yang ditimbulkan energi kinetik hujan pada permukaan tanah yang tidak tertutupi vegetasi.

Tabel 4. Pengelolaan Tanaman (C) dan Tindakan Konservasi Tanah

\begin{tabular}{clcc}
\hline No & \multicolumn{1}{c}{ Titik Sampel } & Nilai C & Nilai P \\
\hline 1 & Kebun - AC & 0,1 & 0,5 \\
2 & Kebun - C 1 & 0,1 & 0,35 \\
3 & Kebun - C 2 & 0,1 & 0,35 \\
4 & Kebun - D & 0,32 & 0,5 \\
5 & Kebun - L & 0,1 & 0,1 \\
6 & Kebun - SC 1 & 0,1 & 0,5 \\
7 & Kebun - SC 2 & 0,1 & 0,35 \\
8 & Pemukiman - AC & 0,2 & 0,35 \\
9 & Pemukiman - C 1 & 0,195 & 0,1 \\
10 & Pemukiman - C 2 & 0,1 & 0,5 \\
11 & Pemukiman - D & 0,1 & 0,1 \\
12 & Pemukiman - L1 & 0,32 & 0,35 \\
13 & Pemukiman - L2 & 0,1 & 0,1 \\
14 & Pemukiman - SC & 0,8 & 0,2 \\
15 & Sawah Tadah Hujan - AC 1 & 0,434 & 0,35 \\
16 & Sawah Tadah Hujan - AC 2 & 0,8 & 0,35 \\
17 & Sawah Tadah Hujan - C 1 & 0,1 & 0,35 \\
18 & Sawah Tadah Hujan - C 2 & 0,8 & 0,2 \\
19 & Sawah Tadah Hujan - C 3 & 0,1 & 0,35 \\
20 & Sawah Tadah Hujan - D & 0,1 & 0,4 \\
21 & Sawah Tadah Hujan - L & 0,1 & 0,1 \\
22 & Sawah Tadah Hujan - SC & 0,1 & 0,35 \\
\hline Keterangan: AC = Agak Curam; C = Curam; D = Datar; L = Landai; SC = & & \\
& Sangat Curam; &
\end{tabular}

\section{Pendugaan Erosi}

Hasil pendugaan erosi diklasifikasikan menurut kelas erosi sesuai dengan Tabel 5 yang kemudian disajikan dalam Tabel 6.

Tabel 5. Kelas Erosi

\begin{tabular}{ccc}
\hline No & Besaran & Kriteria \\
\hline 1 & $<15$ ton $/$ ha/th & Sangat Ringan \\
2 & $15-60$ ton/ha/ th & Ringan \\
3 & $60-180$ ton $/$ ha/th & Sedang \\
4 & $180-480$ ton $/$ ha/th & Berat \\
5 & $>480$ ton $/$ ha/th & Sangat Berat \\
\hline \multicolumn{2}{l}{ Sumber: Departemen Kehutanan, 1998 dalam Firdaus 2017}
\end{tabular}

Menurut Sutarno et al., (2013), lahan kering kawasan hutan jati Perhutani yang diolah oleh masyarakat Desa Prawoto, Kecamatan Sukolilo Kabupaten Pati Jawa Tengah merupakan tanah litosol yang didominasi batuan kapur. Tanah tersebut memiliki rata-rata nilai berat volume (BV) $1,153 \mathrm{~g} / \mathrm{cm}^{3}$. Nilai ini berfungsi sebagai 
asumsi berat volume tanah litosol, sehingga nilai pendugaan erosi dapat dikonversi dari ton/ha/tahun menjadi $\mathrm{mm} /$ tahun.

Pada Tabel 5, terdapat lima kelas erosi dengan empat titik sampel yang memiliki kelas erosi sangat ringan, tiga titik sampel dengan nilai erosi ringan, tiga titik sampel yang termasuk dalam kategori erosi sedang, sebelas titik sampel yang memiliki nilai erosi berat dan satu titik sampel pada kelas serosi sangat berat.

Tabel 6. Pendugaan Erosi dan Klasifikasi Kelas Erosi

\begin{tabular}{clcccc}
\hline \multirow{2}{*}{ No } & \multicolumn{1}{c}{ Titik Sampel } & $\begin{array}{c}\text { Pendugaan Erosi } \\
\text { (ton/ha/th) }\end{array}$ & (mm/th) & Luas (ha) $)$ & $\begin{array}{c}\text { Kelas } \\
\text { Erosi }\end{array}$ \\
\hline 1 & Kebun - AC & 330,75 & 22,05 & 18,55 & $\mathrm{~B}$ \\
2 & Kebun - C 1 & 76,85 & 5,12 & 11,29 & $\mathrm{~S}$ \\
3 & Kebun - C 2 & 208,68 & 13,91 & 25,73 & $\mathrm{~B}$ \\
4 & Kebun - D & 12,49 & 0,83 & 4,75 & $\mathrm{sR}$ \\
5 & Kebun - L & 24,23 & 1,62 & 11,94 & $\mathrm{R}$ \\
6 & Kebun - SC 1 & 374,13 & 24,94 & 21,80 & $\mathrm{~B}$ \\
7 & Kebun - SC 2 & 218,71 & 14,58 & & $\mathrm{~B}$ \\
8 & Pemukiman - AC & 185,87 & 12,39 & 17,78 & $\mathrm{~B}$ \\
9 & Pemukiman - C 1 & 29,56 & 1,97 & 10,82 & $\mathrm{R}$ \\
10 & Pemukiman - C 2 & 123,96 & 8,26 & 12,26 & $\mathrm{~S}$ \\
11 & Pemukiman - D & 4,54 & 0,30 & 17,89 & sR \\
12 & Pemukiman - L1 & 114,61 & 7,64 & 6,28 & $\mathrm{~S}$ \\
13 & Pemukiman - L2 & 10,56 & 0,70 & 14,46 & sR \\
14 & Pemukiman - SC & 431,05 & 28,74 & 9,44 & $\mathrm{~B}$ \\
15 & Sawah Tadah Hujan - AC 1 & 316,32 & 21,09 & 29,45 & $\mathrm{~B}$ \\
16 & Sawah Tadah Hujan - AC 2 & 475,45 & 31,70 & & $\mathrm{~B}$ \\
17 & Sawah Tadah Hujan - C 1 & 381,38 & 25,43 & 19,38 & $\mathrm{~B}$ \\
18 & Sawah Tadah Hujan - C 2 & 600,64 & 40,04 & 2,91 & sB \\
19 & Sawah Tadah Hujan - C 3 & 182,10 & 12,14 & 19,38 & $\mathrm{~B}$ \\
20 & Sawah Tadah Hujan - D & 58,51 & 3,90 & 8,40 & $\mathrm{R}$ \\
21 & Sawah Tadah Hujan - L & 14,14 & 0,94 & 12,09 & sR \\
22 & Sawah Tadah Hujan - SC & 191,75 & 12,78 & 14,32 & $\mathrm{~B}$ \\
\hline
\end{tabular}

Keterangan $=\mathrm{AC}=$ Agak Curam; $\mathrm{C}=$ Curam; $\mathrm{D}=$ Datar; $\mathrm{L}=$ Landai; $\mathrm{SC}=$ Sangat Curam; $\mathrm{B}=\mathrm{sR}=$ Sangat Ringan; $\mathrm{R}=$ Ringan $\mathrm{S}=$ Sedang; $\mathrm{B}=$ Berat

Nilai pendugaan erosi terendah terdapat pada pemukiman dengan kemiringan datar yang diduga memiliki besaran erosi 4,54 ton/ha/tahun atau $0,30 \mathrm{~mm} / \mathrm{tahun}$. Hal ini dikarenakan kemiringan lereng yang kecil, pengelolaan tanaman berupa kebun campuran dan penutup tanah yang rapat mampu menghambat air hujan yang turun langsung menyentuh tanah. Menurut Asdak (2010), semakin luas atau rapat tajuk vegetasi semakin banyak air hujan yang dapat ditahan sementara untuk kemudian diuapkan kembali ke atmosfer. Selain itu, pemukiman memiliki tanaman pekarangan yang merupakan tanaman tahunan dengan perakaran kuat dan tanaman semusim yang sering dikombinasikan dengan pemeliharaan ternak yang dapat meminimalisir terjadinya erosi. Upaya konservasi lahan seperti pembuatan saluran air di dekat rumah juga dapat mencegah terjadinya limpasan permukaan yang tidak teratur, karena air mengalir pada satu aliran (Pasaribu et al., 2012). Pendugaan kelas erosi sangat ringan memiliki penyebaran seluas 49,20 ha. Nilai pendugaan erosi tertinggi terdapat pada sawah tadah hujan curam titik 2 dengan nilai erosi yang diduga sebesar 600,64 ton/ha 


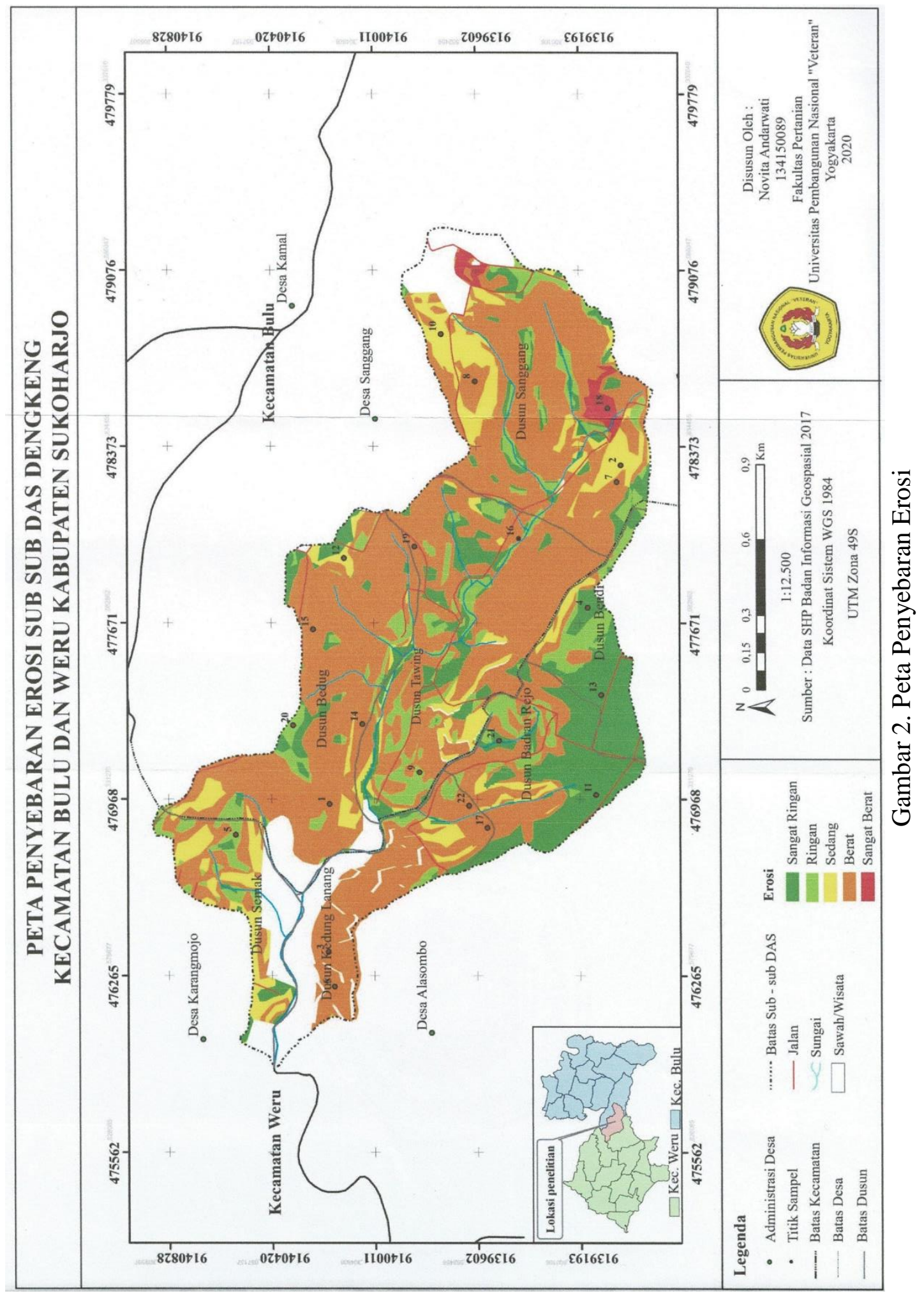


/tahun atau 52,09 mm/tahun. Pada titik sampel ini, nilai pengelolaan tanaman menjadi masalah yang paling menonjol, yaitu ubi kayu. Pemanenan ubi kayu dapat merusak agregat tanah sehingga mempercepat pendispersian tanah. Selain itu, lahan tidak ditanami tanaman lain yang mengakibatkan kerapatan vegetasinya renggang. Menurut Masnang et al., (2014), vegetasi dan lapisan seresah melindungi permukaan tanah dari pukulan langsung tetesan air hujan yang dapat menghancurkan agregat tanah, sehingga terjadi pemadatan tanah. Hancuran partikel tanah akan menyebabkan penyumbatan pori tanah makro sehingga menghambat infiltrasi air tanah, akibatnya limpasan permukaan akan meningkat. Pendugaan erosi pada kelas ini memiliki luasan 2,91 ha.

\section{KESIMPULAN}

1. Erosi tanah yang terjadi di Sub - sub DAS Dengkeng mencakup lima kelas yaitu sangat ringan, ringan, sedang, berat dan sangat berat. Nilai pendugaan erosi terbesar terdapat pada salah satu titik sampel pada penggunaan lahan sawah tadah hujan dengan kemiringan lereng curam yaitu 600,64 ton/ha/tahun atau 40,04 mm/tahun. Kelas erosi ini memiliki luas 2,91 ha. Sedangkan yang terendah terdapat pada titik sampel penggunaan lahan pemukiman di kemiringan lereng datar dengan nilai pendugaan erosi sebesar 4,54 ton/ha/tahun atau $0,30 \mathrm{~mm} /$ tahun. Kelas erosi sangat ringan ini memiliki luas 17,89 ha.

2. Persebaran erosi terluas terdapat pada kelas berat dengan luas 175,27 ha dan kelas erosi sangat berat memiliki luasan paling kecil yaitu 2,91 ha.

\section{DAFTAR PUSTAKA}

Asdak, C. 2010. Hidrologi dan Pengelolaan Daerah Aliran Sungai. Yogyakarta: Gadjah Mada University Press.

As-syakur, A.R. 2008. Prediksi Erosi dengan Menggunakan Metode USLE dan Sistem Informasi Geografis (SIG) Berbasis Piksel Di Daerah Tangkapan Air Danau Buyan. Prosiding PIT MAPIN XVII. Bandung, 10 Desember 2008. Pusat Penelitian Lingkungan Hidup (PPLH) dan Universitas Udayana. h. 1 - 11.

Dariah, A., U. Haryati, dan T. Budhyastoro. 2004. Teknologi Konservasi Tanah pada Lahan Kering Berlereng. Bogor: Pusat Penelitian dan Pengembangan Tanah dan Agroklimat (Puslitbangtanak).

Firdaus, A. N. 2017. "Analisis Bahaya Erosi Permukaan Menggunakan Metode USLE dengan Pemanfaatan Penginderaan Jauh dan SIG di Sub Das Samin, Kabupaten Karanganyar dan Sukoharjo". Skripsi. Surakarta: Universitas Muhammadiyah Surakarta.

Idjudin, A. A. 2011. Peranan Konservasi Lahan dalam Pengelolaan Perkebunan. Jurnal Sumberdaya Lahan 20115 (2) 103 - 116.

Masnang, A., N. Sinukaban, Sudarsono dan N. Ginting. 2014. Kajian Tingkat Aliran Permukaan dan Erosi, pada Berbagai Tipe Penggunaan Lahan di Sub DAS Jenneberang Hulu. Jurnal Agroteknos 20144 (1) 32- 37.

Septianugraha, R. dan A. Suriadikusumah. 2014. Pengaruh Penggunaan Lahan dan Kemiringan Lereng Terhadap C-Organik dan Permeabilitas Tanah Di Sub Das 
Cisangkuy Kecamatan Pangalengan, Kabupaten Bandung. Jurnal Agrin 201418 (2) $158-166$.

Shanshan, W., S. Baoyang, L. Chaodong, L. Zhanbin dan M. Bo. 2018. Runoff and Soil Erosion on Slope Cropland: A Review. J. Resour. Ecol. 20189 (5) 461 - 470.

Suryanto dan Wawan. 2017. Pengaruh Kemiringan Lahan dan Mucuna bracteata Terhadap Aliran Permukaan dan Erosi di PT Perkebunan Nusantara V Kebun Lubuk Dalam. JOM FAPERTA 2017 4(1) $1-15$.

Veihe, A. 2002. The Spatial Variability of Erodibility and Its Relation to Soil Types: A Study from Northern Ghana. Geoderma 1062002 101-120. 